\title{
Characterization of coniferous forest soils in the arid zone
}

\author{
Mohamed Zouidi ${ }^{1,2 *}$, Amine Habib Borsali ${ }^{1,2}$, \\ Ayoub Allam ${ }^{1,2}$ and Raphael Gros ${ }^{3}$
}

Zouidi, M., Borsali, A.H., Allam, A., Gros, R. 2018. Characterization of coniferous forest soils in the arid zone. - Forestry Studies | Metsanduslikud Uurimused 68, 64-74. ISSN 1406-9954. Journal homepage: http:/ / mi.emu.ee/forestry.studies

\begin{abstract}
Arid zones are very harsh environments characterized by binding edaphic and climatic factors, their rainfall is low and irregular accentuated by high temperatures and their soils are fragile and vulnerable. In recent years, it has been noted that vegetation is regressing and that the majority of reforestation has been a failure. Our study aims to know the physico-chemical and microbiological characteristics of forest soils in the pinewoods of an area of the highlands of western Algeria (Naama). For this we analyzed several soil samples spread over five sampling stations in a forest of Aleppo pine. The results show that the forest soils of our study area are characterized by a generally sandy texture and an orange color for all the selected stations. They are characterized by: a very high $\mathrm{C} / \mathrm{N}$ ratio that indicates a slow evolution of organic matter and a nitrogen deficiency that is necessary for carbon decomposition. The conductivity shows that the soil contains some salinity, its permeability is strong and its humidity fairly low with an alkaline $\mathrm{pH}(>8)$ due to the increase in the limestone level in the area. Basal respiration is low compared to microbial biomass due to poor physico-chemical quality of soils and the effect of water stresses that slow down microbial activities. Soils in this arid forest are generally characterized by soil homogeneity sensitive to the influence of environmental factors mainly poverty into elements necessary for its proper functioning such as nitrogen and water that accentuate soil degradation of these forest formations, which results in the risk of degradation being triggered.
\end{abstract}

Key words: forest soil properties, pinewood, aridity, microbial activity.

Author's addresses: ${ }^{1}$ Department of Biology, Faculty of Science. University “Dr Moulay Taher" Saïda, Algeria; ${ }^{2}$ Laboratory "Water Resources and Environment" University of Saïda, Algeria; ${ }^{3}$ Institut Mediterranean Biodiversity and Ecology, UMR CNRS IRD 7263, Team Vulnerability of Microbial Systems, 452 Service, Faculty of Sciences and Techniques of St. Jerome, Aix-Marseille University, 13397 Marseille Cedex 20, France; *e-mail: zouidibiologie20@gmail.com

\section{Introduction}

In Algeria, arid zones account for nearly $95 \%$ of the national territory, of which $80 \%$ is in the Hyper-arid zone (Halitim, 2011). These areas, characterized by a dry and most often warm climate, are highly sensitive to the warming of the atmosphere due to the increase in greenhouse gases since the end of the $19^{\text {th }}$ century (IRD, 2015). The climatic conditions characterised by the low annual average rainfall (between 100 to $300 \mathrm{~mm}$ water per year) and by the high deficit of these in relation to potential evapotranspiration (FAO, 1992). The soil is the living and vital epidermis of the earth's continents, the support of human activities and the place of life of many plant and animal species (Mathieu, 2009).

The soil, although it can be restored and more or less reconstituted, remains a nonrenewable resource because of the long period necessary for its formation processes. This property makes it particularly susceptible to anthropogenic aggression (Gros, 2002). The knowledge of the constituents of the soil, their composition and their main physico-chemical properties, is in any case a prerequisite for the study of the soil medium. This fundamental knowledge makes it possible to undertake the study of soil formation processes (pedogenesis process) 
in relation to environmental conditions, which leads to the classification of world soils and their mapping (Drouet, 2010). This work aims to study the physico-chemical and microbiological quality of forest soils of pinewoods in the arid bioclimatic stage of western Algeria see what are the limiting factors in these soils. In this study we are particularly interested in comparing five stations in a pine forest of Aleppo which is located in the commune of Mecheria, wilaya of Naama.

\section{Material and Methods}

\section{Presentation of the study area}

The Djebel Antar forest is located in the commune of Mecheria in the east of Naama wilaya. This forest is a piedmont area of Djebel that plays a protective role against the desertification of the area. It is a mass afforestation of Aleppo pine aged 40 to 45 years on an area of 1000 ha, on a calcimagnesic soils whose depth is generally between 10 and $30 \mathrm{~cm}$, this reforestation was carried out by the company ONF (National Forestry Office) in the years 1975 and followed by further repopulation in the year eighty. Aleppo pine is used as the main petrol at a rate of $95 \%$. Today, Aleppo pine trees have an average height of between 3 and $5 \mathrm{~m}$. The area has recently encountered several factors of degradation due to desertification and urbanization with the consequence of a radical transformation of the affected plant formations (Benabdelli, 1996). In addition to the risk posed by waste on afforestation as a source of fire, their effect on the health status of the stands is evident. The pressure exerted by pollution on peri-urban plantations is beginning to grow with population growth. The forest benefits from an arid climate $\left(\mathrm{M}=2{ }^{\circ} \mathrm{C}, \mathrm{P}=203.5\right.$ $\mathrm{mm}$ ). The seasonal regime is type APHE (Autumn, Spring, Winter, Summer) with 8 months of drought with a period of jelly that averages over 40 days (ONM, 2015).

\section{Selection of stations and sampling}

Five sampling stations at least $400 \mathrm{~m}^{2}$ were selected in our study area. For each station, five samples of $1 \mathrm{~kg}$ of soil were randomly collected after the litter was eliminated at a depth of 0 to $10 \mathrm{~cm}$. The composite samples were sieved to $2 \mathrm{~mm}$, the samples were air-dried before performing some physicochemical analyses, or kept in $4{ }^{\circ} \mathrm{C}$ while awaiting microbiological analysis (Borsali, 2013) (Table 1).

\section{Physical properties}

The granulometric distribution (\%) 3 fractions of the fine ground (sands of $2000 \mu \mathrm{m}$ to $50 \mu \mathrm{m}$, coarse silt from $50 \mu \mathrm{m}$ to $2 \mu \mathrm{m}$, clays $<2 \mu \mathrm{m}$ ) was determined by sedimentation method of the Robinson pipette (Aubert, 1978). The colors are determined by reference to a code "Munsell soil color chart" (Delaunois, 2006). Water retention capacity was determined by Bouyoucos method. The sample is moistened by capillary rise for 12 hours in a sintered glass filter of Büchner. Finally, the water content of the saturated sample, said the field capacity, was determined by drying cylinder oven $\left(105^{\circ} \mathrm{C}, 24 \mathrm{~h}\right)$. The difference between the wet and dry weight (after drying at

Table 1. Geographical coordinates for the location of study stations.

\begin{tabular}{lccc}
\hline Stations & Altitude $(\mathrm{m})$ & Longitude X & Latitude Y \\
\hline Station 01 & 1280 & $33^{\circ} 32^{\prime} 04.8^{\prime \prime} \mathrm{N}$ & $00^{\circ} 19^{\prime} 25.2^{\prime \prime} \mathrm{W}$ \\
Station 02 & 1240 & $33^{\circ} 32^{\prime} 38.1^{\prime \prime} \mathrm{N}$ & $00^{\circ} 18^{\prime} 42.3^{\prime \prime} \mathrm{W}$ \\
Station 03 & 1219 & $33^{\circ} 32^{\prime} 08.4^{\prime \prime} \mathrm{N}$ & $00^{\circ} 32^{\prime} 08.4^{\prime \prime} \mathrm{W}$ \\
Station 04 & 1185 & $33^{\circ} 32^{\prime} 01.5^{\prime \prime} \mathrm{N}$ & $00^{\circ} 17^{\prime} 06.5^{\prime \prime} \mathrm{W}$ \\
Station 05 & 1208 & $33^{\circ} 31^{\prime} 08.7^{\prime \prime} \mathrm{N}$ & $00^{\circ} 18^{\prime} 42.5^{\prime \prime} \mathrm{W}$ \\
\hline
\end{tabular}


$105^{\circ} \mathrm{C}$ ) allows to know the ability of retention (\%) water dry weight. The water content gravimetric (\% dry weight) was estimated by desiccation of an aliquot of sample at $105^{\circ} \mathrm{C}$ for 24 hours (Mathieu, 1998). The permeability of a soil is the height of water assessed per centimetre that infiltrates the soil per unit of time (Mathieu, 1998). Bulk density is to take samples of the soil of known volume (cylinder) which determine the wet mass and dry mass and thus density. The actual density is to determine the volume of water moved by the solid phase of a sample of mass known in a known volume (density). The porosity was calculated from the density.

\section{Chemical properties}

Total carbon (CT) and total nitrogen (NT) concentrations were measured using a $\mathrm{CN}$ FlashEA 1112 (Thermofisher) elemental analyzer. The $\mathrm{C} / \mathrm{N}$ ratio has been calculated because this parameter is essential in the characterization of a material to be composted. The $\mathrm{pH}$ and conductivity of the soils were measured in a suspension of soil: distilled water (1: 2.5), KCL (1: 2.5). The calcium carbonate $\left(\mathrm{CaCO}_{3}\right)$ contents were determined by Bernard's Calcimètre (Aubert, 1978). The silicon (Si), aluminum $(\mathrm{Al})$, iron $(\mathrm{Fe})$, calcium $(\mathrm{Ca})$, magnesium $(\mathrm{Mg})$ and potassium $(\mathrm{K})$ element contents were determined by X-ray fluorescence in oxidized form on a solid solution sample called lozenge. This procedure is related to the practical instrumental method of basic soil analysis by X-ray fluorescence spectrophotometry.

\section{Biological properties}

Basal respiration ( $\mu \mathrm{g} \mathrm{C}-\mathrm{CO}_{2} / \mathrm{g}$ dry soil) was measured according to the protocol described by Anderson and Domsch (1978) to assess the physiological status of soil microbial communities.

$10 \mathrm{~g}$ (dry equivalent) of fresh soil kept at $4{ }^{\circ} \mathrm{C}$ were weighed in a glass vial $(117 \mathrm{~mL})$. The vials were closed with a hermetically sealed plug immediately after the replace- ment (4 minutes) of their internal atmosphere by a stable $\mathrm{CO}_{2}$ concentration atmosphere and incubated 4 hours at $25^{\circ} \mathrm{C}$. After incubation, an aliquot of atmosphere of the vial $(1 \mathrm{~mL})$ was injected using a syringe into a gas chromatograph (Chrompack CHROM 3 - CP 9001). The chromatograph was equipped with a TCD detector and a filled column (Porapack) in which helium circulates at a flux of $60 \mathrm{~mL} \mathrm{~h}^{-1}$.

The values obtained were adjusted to $22{ }^{\circ} \mathrm{C}$ according to the law of the gases perfect at $\mathrm{Q} 10=2$. Ambient $\mathrm{CO}_{2}$ concentrations were subtracted from the $\mathrm{CO}_{2}$ concentrations measured after incubation to obtain the amount of $\mathrm{CO}_{2}$ produced by the heterotrophic microorganisms contained in the sample.

Microbial biomass was estimated by the glucose-induced respiration method (Anderson \& Domsch, 1978). A mixture of talc and glucose (1 $000 \mu \mathrm{g} \mathrm{C} \mathrm{g}^{-1}$ soil) was added to the ten grams (dry equivalent) of soil. An incubation of 100 minutes was performed to achieve a maximum rate of induced respiration. The vials were closed with an airtight stopper immediately after the replacement (4 minutes) of their internal atmosphere by an atmosphere of stable $\mathrm{CO}_{2}$ concentration, then incubated 90 minutes at $22^{\circ} \mathrm{C}$. The $\mathrm{CO}_{2}$ concentration of the vials was analysed by gas chromatography and corrected in the same way as previously described for basal respiration. Induced respiration rates were converted to microbial biomass value using the equation given by Beare et al. (1990).

\section{Statistical analysis}

Analyses of 1-factor (ANOVA) were used to test the difference in physico-chemical and microbiological properties between different stations studied. The post-hoc test of the lesser differences of Fisher (LSD) was used to achieve homogeneity groups and multiple comparisons of averages between different stations. 


\section{Results}

\section{Physical Properties}

The physical parameters of the soils are recorded in Figure 1. On the basis of the average particle size composition, the soils studied in the different stations have a texture between sandy and sandy clay. According to the "Munsel Color Schart" all stations in our arid zone have a generally orange colour for all stations. Soil moisture is very low between $(4.2 \%$ and $6.2 \%)$ and does not record any significant difference $(p>0.05)$. The retention capacity is on average $(50 \%)$ it is correlated with soil texture and has a moderately significant difference $(p<0.01)$
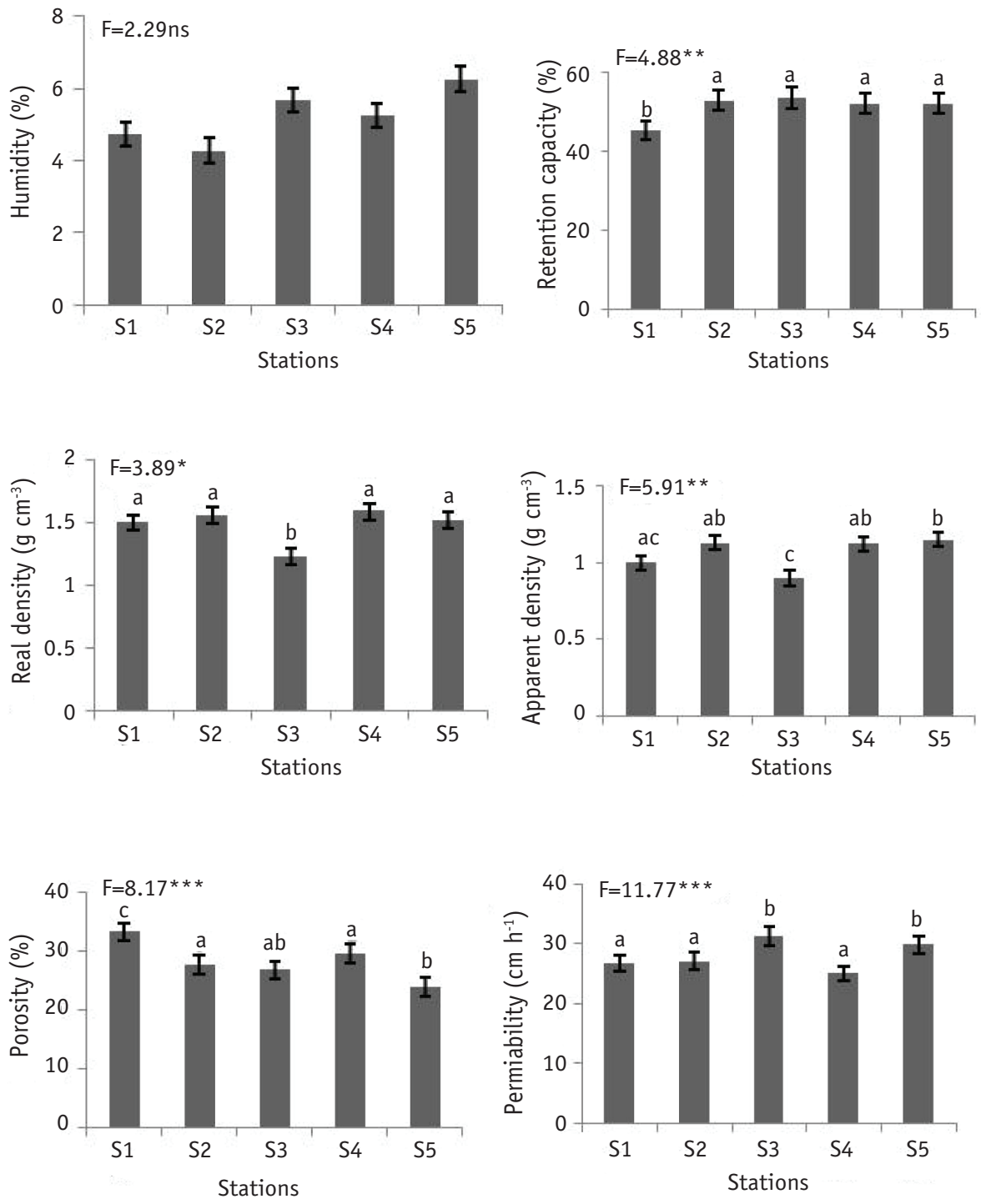

Figure 1. Physical properties of soils.

Averages \pm standard deviations. The $p$ value of independent test is presented with its significance threshold ( ${ }^{*} p<0.05 ;{ }^{* *} p<0.01 ;{ }^{* *} ; p<0.001 ; n s$, not significant). Different letters indicates the homogeneity of the groups (Fisher LSD, $p<0.05$ ). 
apparent densities $\left(0.90 \mathrm{~g} \mathrm{~cm}^{-3}\right.$ and $1.15 \mathrm{~g}$ $\left.\mathrm{cm}^{-3}\right)$ and actual densities $\left(1.23 \mathrm{~g} \mathrm{~cm}^{-3}\right.$ and $1.59 \mathrm{~g} \mathrm{~cm}^{-3}$ ) present average percentages with a small difference.

\section{Chemical properties}

The results of analysis of soil chemical properties in our arid zone (Figure 2) show that the concentrations of organic carbon, total nitrogen are variable from one station to another. However, we recorded a low organic carbon concentration in the $\mathrm{S} 4$ station $\left(4.72 \mathrm{~g} \mathrm{~kg}^{-1}\right)$ and a higher value $\left(7.59 \mathrm{~g} \mathrm{~kg}^{-1}\right)$ marked at S3, S4 stations. The total nitrogen rate remains lower than organic carbon with a value between $\left(0.13 \mathrm{~g} \mathrm{~kg}^{-1}\right)$ for the stations (S2, S3 and S4) and a maximum of $\left(0.23 \mathrm{~g} \mathrm{~kg}^{-1}\right)$ for the station (S1). The organic matter rate is correlated with the organic carbon statistical Study of organic carbon, total nitrogen, $\mathrm{C} / \mathrm{N}$ ratio, and organic matter, shows that there is no significant high difference between the stations in our area $(p<0.001)$.

The results of the $\mathrm{pH}$ of water and $\mathrm{KCl}$ show that the soils studied are alkaline
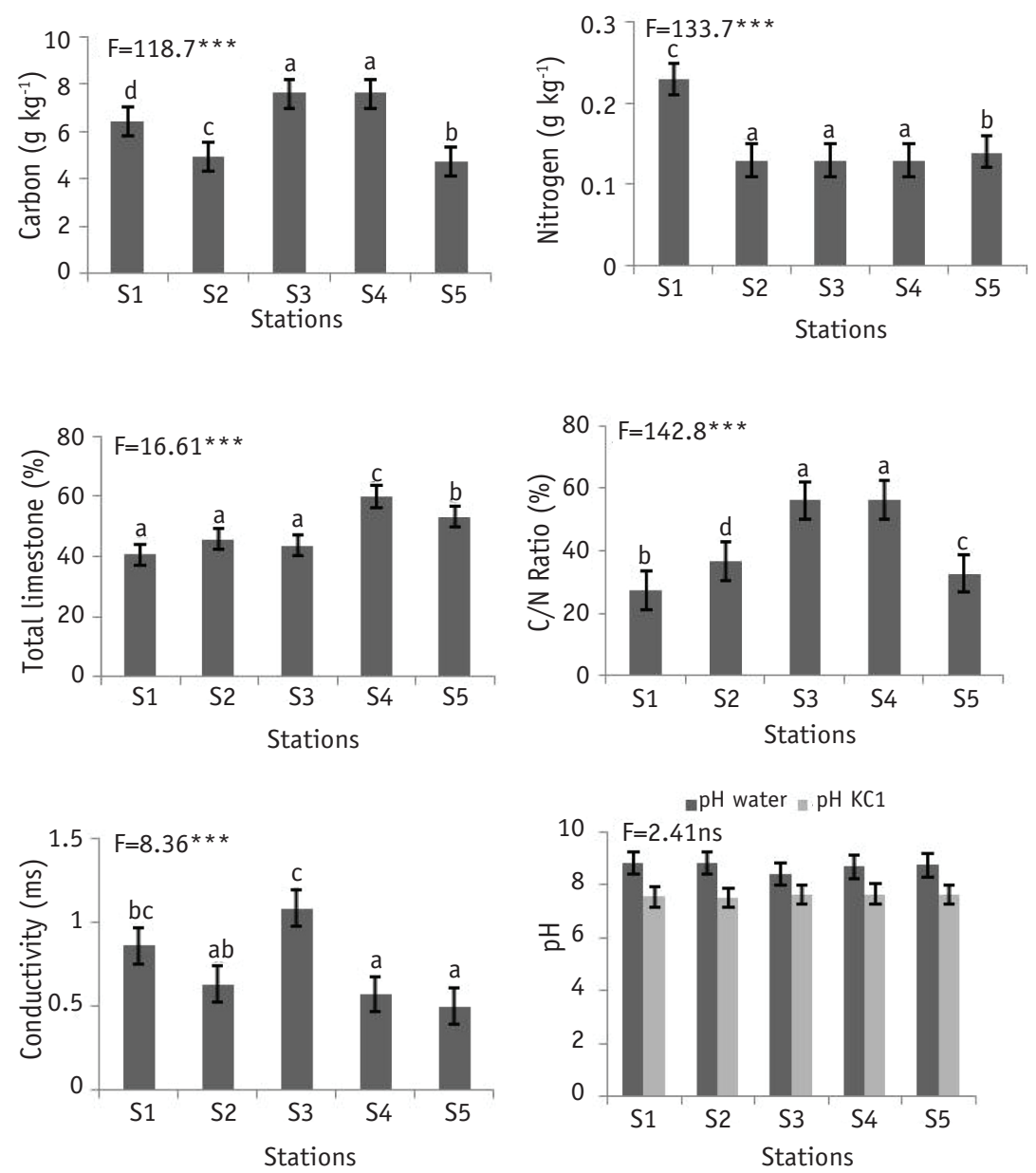

Figure 2. Chemical properties of soils.

Averages \pm standard deviations. The $p$ value of independent test is presented with its significance threshold $\left({ }^{*} p<0.05 ; * *\right.$; $p<0.01 ;{ }^{* *} ; p<0.001 ;$ ns, not significant). Different letters indicates the homogeneity of the groups (Fisher LSD, $p<0.05)$. 

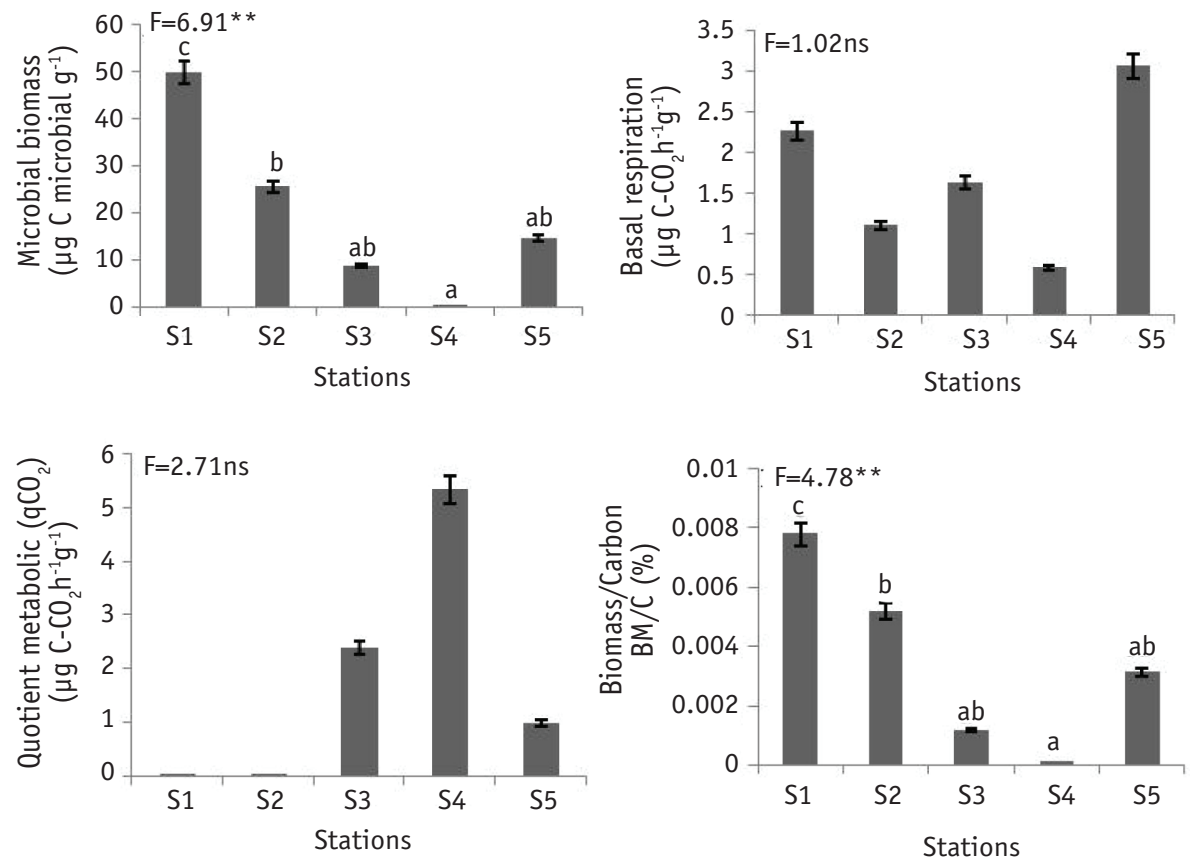

Figure 3. Microbiological properties of soil.

Averages \pm standard deviations. The $\mathrm{p}$ value of independent test is presented with its significance threshold $\left({ }^{*} p<0.05\right.$; ${ }^{* *} p<0.01 ;{ }^{* *} p<0.001 ;$ ns, not significant). Different letters indicates the homogeneity of the groups (Fisher LSD, $p<0.05)$.

soils, with values $(<8)$. The measurement of conductivity shows that the soils studied are classified as low-salted soils (between $0.6 \mathrm{mS}$ and $1.2 \mathrm{mS}$ ) according to the salinity scale of Aubert 1978. The stations studied exhibited a large variable limestone rate and with a highly significant difference $(p<0.001)$ the station (S4) has the maximum value with $60.1 \%$, the minimum limestone rate is $40.8 \%$ in the station (S1), the stations are generally highly calcareous.

For the soil chemical elements (given in oxides) the calcium oxide $(\mathrm{CaO})$ remains positively correlated with the total limestone, the potassium oxide $\left(\mathrm{K}_{2} \mathrm{O}\right)$ also presents this significant difference; The other chemical elements silicon dioxide $\left(\mathrm{SiO}_{2}\right)$, iron oxide $\left(\mathrm{Fe}_{2} \mathrm{O}_{3}\right)$, magnesium oxide $(\mathrm{MgO})$, aluminium oxide $\left(\mathrm{Al}_{2} \mathrm{O}_{3}\right)$ remain homogeneous and show no difference between the soils studied. Silicon dioxide
$\left(\mathrm{SiO}_{2}\right)$ and calcium oxide $(\mathrm{CaO})$ form the dominant chemical elements in the chemical composition of the soils in these stations (Table 2).

\section{Biological properties}

The averages of the soil microbial parameters are set out in Figure 3. From the statistical analysis the results show that there are no significant differences in basal microbial respiration (RB), and measured $\mathrm{qCO}_{2}$ between the stations $(p>0.05)$. Basal respiration was homogeneous between soils studied against microbial biomass (BM) remained variable with a moderately significant difference $(p<0.01)$. The $\mathrm{BM} / \mathrm{C}$ ratio is very low and correlated with microbial biomass and remains moderately significant. 
Table 2. Mineral elements of soils.

\begin{tabular}{|c|c|c|c|c|c|c|}
\hline \multirow{2}{*}{$\begin{array}{l}\text { Oxides of } \\
\text { chemical } \\
\text { elements }\end{array}$} & \multicolumn{5}{|c|}{ Stations } & \multirow{2}{*}{$\begin{array}{c}\text { F- value } \\
\text { and } \\
\text { significance }\end{array}$} \\
\hline & S1 & $\mathrm{S} 2$ & S3 & S4 & S5 & \\
\hline $\begin{array}{l}\text { Iron oxide } \\
\left(\mathrm{Fe}_{2} \mathrm{O}_{3}\right)\end{array}$ & $6.28 \pm 0.38$ & $5.80 \pm 0.18$ & $6.41 \pm 0.28$ & $6.50 \pm 0.97$ & $5.91 \pm 0.36$ & $\mathrm{~F}=1.78 \mathrm{~ns}$ \\
\hline $\begin{array}{l}\text { Silicon } \\
\text { dioxide } \\
\left(\mathrm{SiO}_{2}\right) \\
\end{array}$ & $41.75 \pm 0.92$ & $43.39 \pm 3.67$ & $42.26 \pm 1.29$ & $41.10 \pm 1.23$ & $40.02 \pm 1.26$ & $\mathrm{~F}=2.08 \mathrm{~ns}$ \\
\hline $\begin{array}{l}\text { Magnesium } \\
\text { oxide(Mg0) }\end{array}$ & $0.66 \pm 0.18$ & $0.48 \pm 0.17$ & $0.54 \pm 0.16$ & $0.59 \pm 0.11$ & $0.55 \pm 0.064$ & $F=0.96 n s$ \\
\hline $\begin{array}{l}\text { Aluminium } \\
\text { oxide } \\
\left(\mathrm{Al}_{2} \mathrm{O}_{3}\right)\end{array}$ & $10.48 \pm 0.18$ & $9.96 \pm 0.39$ & $10.85 \pm 0.29$ & $10.69 \pm 0.87$ & $10.09 \pm 0.52$ & $F=2.78 n s$ \\
\hline $\begin{array}{l}\text { Potassium } \\
\text { oxide }\left(\mathrm{K}_{2} \mathrm{O}\right)\end{array}$ & $1.71 \pm 0.005 b c$ & $1.70 \pm 0.004 a b$ & $1.72 \pm 0.008 \mathrm{c}$ & $1.69 \pm 0.011 \mathrm{a}$ & $1.67 \pm 0.025 d$ & $\mathrm{~F}=4.11^{* *}$ \\
\hline $\begin{array}{l}\text { Calcium } \\
\text { oxide }(\mathrm{Ca} 0)\end{array}$ & $21.39 \pm 0.21 \mathrm{ab}$ & $21.74 \pm 0.11 b c$ & $21.19 \pm 0.16 a$ & $22.14 \pm 0.37 \mathrm{~cd}$ & $22.51 \pm 0.72 d$ & $\mathrm{~F}=9.51^{* * *}$ \\
\hline
\end{tabular}

Averages \pm standard deviations. The $p$ value of independent test is presented with its significance threshold ( ${ }^{*} p<0.05 ;{ }^{* *} p<0.01 ;{ }^{* * *} p<0.001 ; n s$, not significant). Different letters indicates the homogeneity of the groups (Fisher LSD, $p<0.05$ ).

\section{Discussion}

In Algeria the arid zones present a biological diversity which is expressed generally by the climate (precipitation and temperature). In its zones the climate is warm and dry by the effect of lengthening of summer droughts as well as the impoverishment and irregularity of the annual slices of rains (Estienne \& Godard, 1970). Plant development depends on climatic factors (precipitation and temperature) and edaphic factors (soil and these characteristics) that ensure nutrient production and biogeochemical cycle. The study of the physical properties of the soil in our arid zone shows a sandyclay texture, according to Bensaid (2006), the majority of the spaces in this region contain sands and clays that cover a limestone slab, they are characterized by a clear yellow horizon well drained and very drying (need for irrigation). They do not hold water and mineral salts they are called calcimagnesic soils, they occupy most of the wilaya of Naama. So the plants are struggling to grow. Sloping, they are very susceptible to erosion. They have a low anionic and cationic exchange capacity (Duchaufour, 1984).

The significant presence of sand in these soils mainly due to desertification in the area influences all other parameters such as moisture, porosity, retention capacity (Bensaid, 2006). Sand with no colloidal particles cannot play any role in the formation of stable aggregates in the soil. It adversely affect soil properties i.e. porosity (Soltner, 2000), but the presence of a proportion of clay transforms the soil into a heavy and compacted soil which aggravates the phenomenon of soil erosion (Aubry, 2013). Podwojewski (2007) has shown that in arid and semi-arid regions that soils that have been trampled and whose structure has been destroyed by overgrazing may cause compaction and a surface crust with loss of retention capacity of these soils. The colour of the soil of the forest massif of the arid zone results in my opinion of the mixture of the white colour resulting from the large 
presence of limestone and iron with a reddish colour, under the influence of solar radiation this gives an orange colour. Antonio (2014) showed that the orange colour is part of the secondary colours composed of red and yellow. The low moisture content in arid soils $(4.3 \%-6.3 \%)$ can be explained by the impact of the texture that infiltrates the water and reduces the retention capacity by effect of high porosity but also the depth of soils in arid regions are often limited (FAO, 1992). Anthropogenic degradation of the plant mat results in an increase in temperature and soil maximums that reduce water storage capacity by evaporation (Floret \& Pontanier, 1982). Soil settlement in our forest by overgrazing and soil compaction is accompanied by an increase in its apparent density, which is manifested by a decrease in porosity $(23.8 \%-33.2 \%)$ (Lefèvre \& Lévy, 2001). In our area according to the study of Bensaid (2006), evapotranspiration is much higher than rainfall is 7 times higher than the value of rainfall and this dominance of evapotranspiration generates and/or promotes the process of fragility and of soil degradation and in particular the silting of land and rangelands in the area.

The chemical quality of a soil is controlled by external factors (geographical location, climate, connections with neighbouring ecosystems) but also by internal factors (microbial activity, relationship between organisms) that regulate the availability of the chemical resource (Tessier et al., 1996). The results of the chemical properties show that the soils of the pine forests in our arid zone present more carbon in comparison with the nitrogen which originates from organs and organisms dead, essentially vegetal (the fall of the needles of Aleppo pine). According to Aubert (1960) the soils of the arid zone have a number of constant characters: slow evolution, often reduced depth, highly evolved organic matter, not abundant and superficial or a little more abundant and distributed throughout the profile this is probably due to the increase in the duration of stor- age (residence) of carbon in the soil which varies between an average length of a few decades, but which is very variable since it can go from a few hours to several millennia (Chenu et al., 2014). The soils in our area are limestone with an average of $(48.8 \%)$ and can salty, this important presence of limestone ensures the storage of the latter in the soil according (Trachaud, 1994). Aubert (1960) shows in these works that more calcareous and salinity soils are observed in Algeria and Tunisia than in Morocco. The levels of $\mathrm{CaCO}_{3}$ in carbonated soils are extremely variable: from a few $\%$ to more than $70 \%$ and the most abundant carbonate is calcite (Drouet, 2010). In arid regions, soils, in general, pose enormous problems of development. They often have calcareous or gypsum crusts and are mostly salty and prone to erosion and secondary salinization (Aubert, 1960).

The residence time of the carbon in the soil depends on the composition of the organic matter and the local conditions (soil origin, clay content, temperature, humidity, aeration etc.) (Girard et al., 2011; Chenu et al., 2014). Our results show a higher C/N ratio in S3 and S4 stations with 56.1 and 56.3 respectively. This shows the evolution of the organic matter tending towards the humification $(\mathrm{C} / \mathrm{N}>40)$ and which leads to a net immobilization of soil nitrogen (nitrogen starvation phenomenon for the plant) (Duchaufour, 1988; Baise, 2000) while in the other stations (S1, S2, S5) $(20<\mathrm{C} / \mathrm{N}$ $<40$ ) has a temporary equilibrium but the soil remains in need of covered nitrogen to allow good decomposition of the carbonaceous material. The $\mathrm{C} / \mathrm{N}$ ratio is one of the quality indices of organic matter products (Huber \& Schaub, 2011). The soils are alkaline, a pH between 8 and 9 is retained, usually as a limit of the degradation of the structure (Aubert, 1983), these values are consistent with those reported by (Daoud \& Halitim, 1994), which state that in arid regions, soils are generally alkaline $(7.5<\mathrm{pH}$ $<8.5$ ). The presence of carbonates strongly influences soil reaction, with carbonate soils 
distinguished by a $\mathrm{pH}$ that is still higher than 7 (Drouet, 2010). For the soil chemical elements $\mathrm{SiO}_{2}$ and $\mathrm{CaO}$ are the most dominant elements in the soil, $\mathrm{SiO}_{2}$ (silicon) (> $40 \%$ ) It is considered to be the most abundant element of the earth's crust (Deferne \& Engel, 2016), the calcium carbonate $\left(\mathrm{CaCO}_{3}\right)$ comes from the limestone in the zone, the other chemical elements is found with a small amount in all soils to study.

Physical and chemical degradation, which are the main and first processes, often results in biological degradation (Robert \& Stengel, 1999). Microbiological soil study shows that microbial biomass is significant from one station to another $(0.69-49.79 \mu \mathrm{g}$

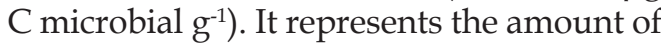
live carbon contained in soil microbes this biomass varies in function of stressful climatic conditions that may limit microbial recolonization. Borsali (2013) shows that water levels strongly control microbial biomass, which has an overall mean of $(19.9 \mu \mathrm{g} \mathrm{C}$ microbial g-1 < $100 \mu \mathrm{g})$ in our arid forest, this biomass is very low according to the interpretation standards of the biomass (Lechevallier et al., 2004; Salducci, 2007), the same principle on the $\mathrm{BM} / \mathrm{C}$ ratio which has an average of $0.003 \%$ this average remains below $0.5 \%$ which means a very low value of microbial biomass in comparison with carbon (Salducci, 2007).

These results show that the physicochemical environment in the arid zone is unfavourable to microbial activity (compaction, soil settlement) more generally and a lack or poor quality of organic refunds (Lechevallier et al., 2004). Basal respiration signifies soil microbial activity based on the amount of $\mathrm{CO}_{2}$ released and the absorbed $\mathrm{O}_{2}$, our results show that despite the significant difference in microbial biomass between stations, basal respiration remains almost even (not significant), and this is probably due to a dormancy of some bacteria as a result of soil-climatic conditions. Microbial activity is mainly dependent on soil conditions (aeration, moisture, porosity, microbial life). The activation of microbial life requires the presence of easily degradable organic matter that will serve as food. It is the interactions between the different soil properties that give it its ability to feed the plant in the long term (Huber \& Schaub, 2011). Return dynamics are therefore highly variable and depend on the amount of resources available, the adaptation of communities, and the stressful climatic conditions that may limit microbial recolonization (Borsali, 2013), including soil moisture decreases water content and increases recalcitrant carbon levels to microbial biodegradation (Borsali et al., 2012). Soil degradation in the arid zone is probably primarily related to anthropogenic action including overgrazing and in the background to other factors such as wind and water erosion of soils with low vegetation, or results in an effect of splash and abrasion, then transporting fragments of minerals and chemical elements; winds, sometimes violent, can carry sand and fine particles from the ground and even the mother stone (Aubry, 2013). Prolonged drought cycles that have occurred in recent years on several occasions and in several parts of the world are changing the parameters governing soil behaviour and giving rise to new soil areas (Laouar \& Houam, 2011) and disturbances in the physicochemical and structural heterogeneity of soils may influence certain biotic and abiotic properties directly involved in the survival of these organisms (Ranjard et al., 2000).

\section{Conclusions}

The present work highlights the imprint of the arid bioclimatic floor on forest soils of pinewoods in the western Algerian. Land degradation in arid areas is caused by extreme weather events (high temperatures and erratic rainfall) and land use and management techniques (clearing and overgrazing); this degradation is characterized by the alteration of these properties. Physicochemical and biological results in the decrease of this fertility and productivity. 
This work gives us an idea of the physicochemical and biological characteristics of these soils and their fragility. Forest soils in arid regions are characterized by textures dominated by sand with a low proportion of clays and are generally unfavourable to roots and microorganisms, and act adversely on the physical properties of soils, especially the reduction of water reserves.

The study of the chemical properties shows a significant presence of carbon which remains higher in comparison with the nitrogen rate, this difference gives a high ratio $(\mathrm{C} / \mathrm{N})$ which shows slow mineralization of the organic matter. The richness of limestone soils and the effect of the arid climate prevent degradation of organic matter and reduce microbial biomass. Measurement of conductivity has shown that these soils are generally saline, microbial activity is very low in arid areas due to drought and soil evaporation. In the end, arid zones are characterized by extremely fragile ecosystems vulnerable to wind and water erosion. The irrational and excessive exploitation of arid lands leads to an inevitable degradation of the vegetation cover and exposes the soil to erosion. Human activities related to land use can therefore aggravate the effects of climate and lead to desertification.

Acknowledgements. We would like to thank the team vulnerability of microbial systems, Institute of Mediterranean Biodiversity and Ecology (IMBE), University of Aix-Marseille, France for chemical and biological soil analysis. This work is part of a doctoral research on the impact of aridity on soils and litters in the forests of Aleppo pines in western Algeria and is part of a research project (PRFU) on agricultural and forestry soils in the arid zone facing to the stresses of climate change and anthropogenic action: what indicators to assess their vulnerabilities and allow their restorations?

\section{References}

Anderson, J.P.E., Domsch, K.H. 1978. A physiological method for the quantitative measurement of microbial biomass in soils. - Soil Biology Biochemistry Journal, 10, 215-221.

Antonio, J. 2014. Soil color never lies, blog of soil system science. [WWW document]. - URL http:/ / blogs.egu.eu/divisions/sss/2014/03/30/soilcolor-never-lies/ [Accessed 05 May 2017].

Auber, G. 1960. The soils of the arid zone: Study of their formation, their characters, their use and their conservation. - UNESCO/NS/AZ/s - 14 eme Colloque de Paris Communication, 5, $30 \mathrm{pp}$. (In French).

Aubert, G. 1978. Methods of soil analysis. CRDP, Marseille, 360 pp. (In French).

Aubert, G. 1983. Observations on characteristics, denomination and classification of salty or salsodic soils. - Cahiers ORSTOM, Série pédologie, 20(1), 73-78. (In French).

Aubry, C. 2013. Urban agriculture. Contributor to food strategies megapoles. Daniel Thevenot. - Proceedings of the $24^{\text {th }}$ scientific days of the environment. The ecological transition of megacities, February 2013, Créteil, France, JSE-2013(5), 12 pp. (In French).

Baise, D. 2000. Guide to analyzes in pedology. INRA, Paris, 257 pp. (In French).

Beare, M.H., Neely, C.L., Coleman, D.C., Hargrove, W.L. 1990. A substrate-induced respiration (SIR) method for measurement of fungal and bacterial biomass on plant residues. - Soil Biology Biochemistry Journal, 22, 585-594.

Benabdelli, K. 1996. Physionomico-structural and dynamic aspects of forest ecosystems in the face of anthropozoogenic pressure in the Tlemcen mountains and the dhaya mountains (Western Algeria). Doctoral thesis, University of Djilali Liabes, Sidi Bel Abbes, 356 pp. (In French).

Bensaid, A. 2006. GIS and remote sensing for the study of silting in an arid zone: the case of the wilaya of Naama (Algeria). Doctoral thesis, University Joseph-Fourier - Grenoble I. France, 319 pp. (In French).

Borsali, A.H. 2013. Contribution to the evaluation of the impact of fires on forest ecosystems: case of Fénouane Forest, municipality of Ain El Hadjer, Saida Province (Algeria). Doctoral thesis, AixMarseille, France, 213 pp. (In French).

Borsali, A.H., Benabdeli, K., Gros, R. 2012. Post-fire reconstitution of the physico-chemical and microbiological properties of Algerian forest soils (Fénouane forest, Saïda wilaya). - Ecologia Mediterranea, 38(1), 57-74. (In French).

Chenu, C., Klumpp, K., Bispo, A., Angers, D., Colnenne, C., Metay, A. 2014. Storing carbon in agricultural soils: evaluation of levers of action for France. - Agronomic Innovations, (37), 23-37. 
Daoud, Y., Halitim, A. 1994. Irrigation and salinization in the Algerian Sahara. - Science and Global Changes - Drought, 5(3), 151-160. (In French).

Deferne, J., Engel, N. 2016. The fascinating world of rocks, 52 pp. (In French).

Delaunois, A. 2006. Simplified guide for soil description, 37 pp. (In French).

Drouet, T. 2010. Pedology. BING-F-302. Lagev, 140 pp. (In French).

Duchauffour, Ph. 1988. Pedology abbreviations. $2^{\text {nd }}$ edition. Masson, Paris, Milan, Barcelona, Mexico, 224 pp. (In French).

Duchaufour, $\mathrm{Ph}$. 1984. Introduction to soil science. $6^{\text {th }}$ edition of the Abstract of Pedology. Dunod, Masson, Paris, 314 pp. (In French).

Estienne, P., Godard, A. 1970. Climatology. Paris, Armand Cohn Edition, 365 pp. (In French).

FAO. 1992. Dryland forestry - A guide for field technicians. [WWW document]. - URL http:/ / www. fao.org/docrep/T0122F/t0122f00.htm\#Contents [Accessed 19 December 2016]. (In French).

Floret, C., Pontanier, R. 1982. Aridity in pre-Saharan Tunisia, climate, soil, vegetation and development. Works and Documents of ORSTOM. Paris, 150 544. (In French).

Girard, M.C., Walter, C., Remy, J.C., Berthelin, J., Morel, J.L. 2011. Soils and the environment. $2^{\text {nd }}$ Edition-Courses, Exercises and Case Studies-Book Complements Online: Courses, Corrected Exercises and Case Studies. Dunod, 896 pp. (In French).

Gros, R. 2002. Functioning and quality of soils subjected to physical and chemical disturbances of anthropogenic origin: responses of soil, flora and telluric bacterial microflora. Doctoral thesis, University of Savoie, 243 pp. (In French).

Halitim, A. 2011. Aridoculture and sustainable development. - Algerian Journal of Arid Environment, 3(1), 3-9. (In French).

Huber, G., Schaub, C. 2011. Soil fertility: The importance of organic matter. Chamber of agriculture of Bas-Rhin, 46 pp. (In French).

IRD. 2015. The climate under surveillance (Educational file), 46 pp. [WWW document]. - URL www.climat-sous-surveillance.ird.fr [Accessed 18 march 2017].

Laouar, M.S, Houam, A. 2011. The natural cementation and compactness state of macroporous soils experimental study, 73-82. (In French).

Lechevallier, C., Planques, B., Salducci, X. 2004. Evaluating the biological dynamics of soils: Analyzes of biological fertility, a beneficial element for plants.
Phytoma-The Defense of Plants, 568, 41-43. (In French).

Lefèvre, Y., Lévy, G. 2001. The forest and its culture on ground with temporary tablecloth. National School of Rural Engineering, Water and Forests. ENGREF, 157-158. (In French).

Mathieu, C. 1998. Physical Analysis of Soils. Paris, 275 pp. (In French).

Mathieu, C. 2009. The main soils of the world. travel through the living epidermis of the planet. Lavoisier, 260 pp. (In French).

Mathieu, C., Pieltain, F. 2003. Chemical analysis of soils. Selected methods. France, 387 pp. (In French).

ONM. 2015. National office of meteorology. Collection of climate data from the wilaya Naama. Daily surveys leaves of the period 1985-2015. [WWW document]. - URL:/ / www.meteo.dz/climatenalgerie. php [Accessed 10 May 2017]. (In French).

Podwojewski, P. 2007. Constituents and properties of soil for a layout use. Effects of the change in use on the constituents and properties of soil. Enabling a leading research, University Pierre and Marie Curie, Paris VI. (In French).

Ranjard, L., Poly, F., Nazaret, S. 2000. Monitoring complex bacterial communities using cultureindependent molecular techniques: application to soil environment. - Research in Microbiology, 151(3), 167-177.

Robert, M., Stengel, P. 1999. Soils and agriculture: soil resource, quality and degradation process. A global, European and French prospective. - Cahiers Agricultures, 8(4), 301-308.

Salducci, X. 2007. Quality of soil organic matter: a new generation of routine analysis. Proceedings of the $8^{\text {th }}$ meetings of the reasoned fertilization and land analysis of COMIFER and GEMAS, November 20-21, 2007, 9 pp. (In French).

Soltner, D. 2000. The basics of crop production, Tome I: Soil and its improvement. $22^{\text {nd }}$ edition, Editions Science and agricultural techniques "Le Clos Lorelle" - 49130 St. Gemmes-Sur-Loire, 472 pp. (In French).

Tessier ,D., Bruand, A., Le Bissonnais, Y., Dambrine, E. 1996. Chemical and physical soil quality: spatial variability and evolution. - Study and Management of Soils, special issue 3/4, 229-244. (In French).

Trachaud, L. 1994. Post-fire plant community dynamics in the Mediterranean basin. The Role of Fire in Mediterranean-type Ecosystems, 1-15. 